\title{
Chemical Composition and Immunobiological Activities of Sodium Dodecyl Sulphate Extracts from the Cell Envelopes of Actinobacillus actinomycetemcomitans, Bacteroides gingivalis and Fusobacterium nucleatum
}

\author{
By KEIJIRO KATO, ${ }^{\text {* }}$ SUSUMU KOKEGUCHI, ' HIROKO ISHIHARA, ${ }^{1}$ \\ YOJI MURAYAMA, ${ }^{2}$ MASACHIKA TSUJIMOTO, ${ }^{3}$ \\ HARUHIKO TAKADA, ${ }^{3}$ TOMOHIKO OGA WA ${ }^{3}$ AND SHOZO KOTANI ${ }^{3}$ \\ 'Department of Oral Microbiology and 'Department of Periodontology and Endodontology, \\ Okavama University Dental School, 2-5-1 Shikata-Cho, Okayama 700, Japan \\ ${ }^{3}$ Department of Oral Microbiology, Osaka University Dental School, 1-8 Yamadaoka, \\ Suita 565, Japan
}

(Received 29 July 1986; revised 21 November 1986)

\begin{abstract}
The chemical composition and immunobiological activities in vivo and in vitro of sodium dodecyl sulphate extracts (SDS-SE) derived from periodontopathic bacteria (three strains of Actinobacillus actinomycetemcomitans, two strains of Bacteroides gingivalis, and one strain of Fusobacterium nucleatum) were investigated. The main components of SDS-SE were protein and lipid, with negligible amounts of peptidoglycan and lipopolysaccharide. Immunopotentiating activity was detected in both delayed-type hypersensitivity and antibody formation against the elicitation of a protein antigen with the SDS-SE preparations of $A$. actinomycetemcomitans ATCC 29524 and $B$. gingivalis 381 and 1021. On the other hand the SDS-SE of $A$. actinomycetemcomitans ATCC 29522 enhanced only the induction of a delayed-type hypersensitivity response. All the SDS-SE preparations had mitogenic activity to splenocytes from $\mathrm{BALB} / \mathrm{c} n u / n u, \mathrm{C} 3 \mathrm{H} / \mathrm{HeN}$ and $\mathrm{C} 3 \mathrm{H} / \mathrm{HeJ}$ mice. Migration-stimulating activity for human peripheral blood monocytes was detected especially in the SDS-SE preparations of $\boldsymbol{A}$. actinomycetemcomitans ATCC 29524 and Y4. All of the SDS-SE samples inhibited $\left[{ }^{3} \mathrm{H}\right]$ thymidine uptake in human gingival fibroblasts and caused degradation of the cells. The results suggest that the cell membrane components extractable with sodium dodecyl sulphate from periodontopathic bacteria are involved in the pathogenesis of periodontal disease.
\end{abstract}

\section{INTRODUCTION}

In periodontal lesions, accumulation of supra- or subgingival plaque proceeds to inflammation of the gingiva, and other reactions, such as denaturation of collagen and alveolar bone loss (Macrina \& Ranney, 1982). Gram-negative anaerobic rods in subgingival plaque play an important role in periodontal destruction by two different mechanisms. The causes of periodontal disease are supposed to be the direct toxicity of the bacterial cell components (Hausmann et al., 1975; Baehni et al., 1981; lino \& Hopps, 1984; Progulske et al., 1984), toxic bacterial metabolites (Singer \& Buckner, 1981) and the consequence of both humoral and cellmediated immune reactions against bacterial-cellular components (Lehner, 1975; Page \& Schroeder, 1981). Murayama et al. (1982) found that among the cellular fractions of a periodontopathic Capnocytophaga sp., the SDS-soluble fraction from the cell envelope showed

Abbretiations: FBS, foetal bovine serum; FMLP, $N$-formyl-L-methionyl-leucyl-phenylalanine; KDO, 2-keto-3deoxyoctonate; MDP, muramyl dipeptide: PHA, phytohaemagglutinin; SDS-SE, SDS-soluble extract; SE, soluble extract. 
the most immunobiological activity. The aim of the present study was to examine SDS extracts from the cell envelopes of Actinobacillus actinomycetemcomitans, Bacteroides gingivalis and Fusobacterium nucleatum, all bacteria associated with periodontopathic disease, for such immunobiological activities.

\section{METHODS}

Growth conditions. A. actinomycetemcomitans strains Y4 (originally isolated from the gingival sulcus of a patient with juvenile periodontitis by S. S. Socransky, Forsyth Dental Center, Boston, Mass., USA : Baehni et al., 1979), ATCC 29522 (isolated from a mandibular abscess) and ATCC 29524 (isolated from a chest aspirate) were grown in brain-heart infusion broth (Difco) supplemented with $0.5 \%(\mathrm{w} / \mathrm{v})$ yeast extract (Difco) and $0.05 \%(\mathrm{w} / \mathrm{v})$ cysteine hydrochloride (Wako Pure Chemical Industries). F. nucleatum ATCC 25586 (isolated from a cervicofacial lesion) was grown in a similar medium except that $0.075 \%$ cysteine hydrochloride was used. ATCC strains were obtained from the American Type Culture Collection (Rockville, Md, USA). B. gingivalis strains 381 and 1021 (isolated from subgingival plaque) were generous gifts from S. S. Socransky; they were grown in brain-heart infusion broth supplemented with $0.0005 \%(\mathrm{w} / \mathrm{v})$ haemin and $0.0001 \%(\mathrm{w} / \mathrm{v})$ vitamin $\mathrm{K}(\mathrm{Wako})$.

All strains were incubated under anaerobic conditions in a chamber containing $\mathrm{N}_{2} / \mathrm{CO}_{2} / \mathrm{H}_{2}(80: 10: 10$, by vol.) (Yuyama Irika, Osaka) at $37^{\circ} \mathrm{C}$ for $72 \mathrm{~h}$. The cells were collected by centrifugation at $10000 \mathrm{~g}$ for $20 \mathrm{~min}$, washed twice with $10 \mathrm{mM}$-phosphate-buffered saline $\mathrm{pH} 7.0$ (PBS), once with distilled water and finally lyophilized.

Preparation of cell envelopes, soluble extract (SE) and SDS-SE. Glass beads $(5.0 \mathrm{~g} ; 0.18 \mathrm{~mm}$ diam., Takashima Shoten, Tokyo) were added to a suspension containing $1 \mathrm{~g}$ lyophilized bacterial cells in $40 \mathrm{ml} 50 \mathrm{~mm}$-phosphate buffer $\mathrm{pH} 7 \cdot 0$, and the mixture was sonicated in a machine (type UR-200P, Tomy Seiko, Tokyo) with an output of $185-200 \mathrm{~W}$ for $15 \mathrm{~min}$ at $4{ }^{\circ} \mathrm{C}$. The sonicated cell suspensions were centrifuged at $1000 \mathrm{~g}$ for $20 \mathrm{~min}$ to remove undisrupted cells, and the supernates were pooled and centrifuged at $100000 \mathrm{~g}$ for $60 \mathrm{~min}$. The supernate was dialysed repeatedly against distilled water at $4{ }^{\circ} \mathrm{C}$ (soluble extract, SE) and lyophilized. The pellet was washed three times with distilled water, suspended in $40 \mathrm{ml}$ distilled water, mixed with an equal volume of $2 \%(\mathrm{w} / \mathrm{v}) \mathrm{SDS}$, stirred at $22{ }^{\circ} \mathrm{C}$ for $24 \mathrm{~h}$ and centrifuged at $100000 \mathrm{~g}$ for $60 \mathrm{~min}$. The supernate was dialysed against distilled water containing $1.5 \%(\mathrm{w} / \mathrm{v})$ Dowex-1 $\times 1$ (Dow Chemical Co.) at $4{ }^{\circ} \mathrm{C}$ for $5 \mathrm{~d}$. The ion-exchange resin suspension was changed twice a day. The dialysed extract was centrifuged at $20000 \mathrm{~g}$ for $30 \mathrm{~min}$ to remove small amounts of insoluble material. The final supernate was lyophilized (SDS-soluble extract, SDS-SE).

Analytical methods. Hexose, pentose and methylpentose were detected by the anthrone (Ashwell, 1957), orcinol (Ashwell, 1957) and cysteine/sulphuric acid (Dische \& Shettles, 1948) methods, respectively. Glycerol and total phosphate were estimated by the methods of Lambert \& Neish (1950) and Lowry et al. (1954), respectively. Protein was determined by the Lowry method. 2-Keto-3-deoxyoctonate (KDO) was quantified by the method of Weissbach \& Hurwitz (1959) after hydrolysis of the SDS-SE samples in $0.005 \mathrm{M}-\mathrm{H}_{2} \mathrm{SO}_{4}$ at $100{ }^{\circ} \mathrm{C}$ for $20 \mathrm{~min}$. The quantity of SDS bound to protein was assessed by the partition detergent/dye salt method of Hayashi (1975); serum albumin and oleic acid were used as references for the correction.

Qualitative and quantitative analyses of amino acids and amino sugars were performed with an amino acid analyser (type 835, Hitachi). Specimens were hydrolysed with $6 \mathrm{M}-\mathrm{HCl}$ in a sealed tube under $\mathrm{N}_{2}$ at $100{ }^{\circ} \mathrm{C}$ for $14 \mathrm{~h}$. Hydrolysates were evaporated under reduced pressure and dried in a vacuum-desiccator containing solid $\mathrm{NaOH}$ to remove $\mathrm{HCl}$. No corrections were made for the destruction of amino sugars and amino acids during the acid hydrolysis.

Gas-liquid chromatography (GLC) of fatty acids. Fatty acids were analysed, after methanolysis, in a gas -liquid chromatograph (type 163, Hitachi) with a column $(200 \mathrm{~cm})$ of $10 \%(\mathrm{w} / \mathrm{v})$ DEGS on Chromosorb W as described by Ikemoto et al. (1978), with cis-11-eicosenoic acid (P. L. Biochemicals) as an internal standard. Hydroxylated fatty acids were also methylated and separated on Kieselgel $60 \mathrm{~F}_{2 s_{4}}$ plates $(20 \times 20 \mathrm{~cm}$, Merck) in light petroleum (b.p. $\left.30-60{ }^{\circ} \mathrm{C}\right) /$ diethyl ether $(1: 1, \mathrm{v} / \mathrm{v})$ at room temperature for $60 \mathrm{~min}$. $\beta$-Hydroxymyristic acid (Wako) and $\beta$ hydroxypalmitic acid (isolated from Azospirillum brasilense JCM 1225: Ohta \& Hattori, 1983) were used as references. The separated hydroxylated fatty acids were detected by spraying the plate with $0.02 \%(w / v)$ rhodamine $6 \mathrm{G}$ in ethanol, and examining it under ultraviolet irradiation. The zones of reaction were collected by scraping the Kieselgel off the plate and extracting with diethyl ether. The fatty acids in these samples were quantified by GLC.

Limulus assay. The endotoxin content of SDS-SE samples was determined by the Limulus Toxicolor test (Iwanaga $e t$ al., 1978) by courtesy of M. Ooki and S. Tanaka, Tokyo Institute of Seikagaku Kogyo, Tokyo.

$S D S$-polyacrylamide gel electrophoresis (SDS-PAGE). This was done with $10 \%(\mathrm{w} / \mathrm{v})$ acrylamide in $0.1 \%(\mathrm{w} / \mathrm{v})$ SDS in a vertical slab gel apparatus according to Laemmli (1970), with slight modification. Slab gels were fixed and stained with $10 \%(\mathrm{v} / \mathrm{v})$ acetic acid, $45 \%(\mathrm{v} / \mathrm{v})$ methanol, $0.1 \%(\mathrm{w} / \mathrm{v})$ Coomassie brilliant blue $\mathbf{R}$ at room temperature for $1 \mathrm{~h}$, and destained overnight with $7.5 \%$ acetic acid, $10 \%$ methanol at room temperature. The following marker proteins (Oriental Yeast Co. and Seikagaku Kogyo Co.) were used for molecular mass 
calibration: RNA polymerase $(\beta, 140 \mathrm{kDa})$, horse heart muscle cytochrome $c$ (hexamer, $74.4 \mathrm{kDa}$; tetramer, $49.6 \mathrm{kDa}$; trimer, $37.2 \mathrm{kDa}$; dimer, $24.8 \mathrm{kDa}$; and monomer, $12.4 \mathrm{kDa}$ ).

Assay of immunopotentiating activity. The immunoadjuvant activity in vivo was tested as described by Kotani $e t$ al. (1975). Groups of five female guinea-pigs were injected in the left hind food-pad with $0.2 \mathrm{ml}$ of an emulsion prepared by mixing $1.0 \mathrm{mg}$ ovalbumin (grade V, Sigma) as immunogen and $0.1 \mathrm{mg}$ SDS-SE, both dissolved in PBS, with Freund's incomplete adjuvant (Difco). The delayed-type hypersensitivity reaction to ovalbumin was measured by the corneal reaction, and the anti-ovalbumin precipitin titre was assayed 3 and 4 weeks after immunization.

The mitogenic acticity of SDS-SE. The effect of SDS-SE preparations $(0 \cdot 1,1$ and $10 \mu \mathrm{g})$ on mouse splenocytes was assayed by measuring the incorporation of $\left[{ }^{3} \mathrm{H}\right]$ thymidine (Takada et al., 1979). Splenocytes were isolated from BALB/c nu/nu (6-week-old Nihhon Clea, Tokyo), C3H/HeN (female, 10-week-old, Nihhon Charles-River, serum Atsuki, Saitama) and $\mathrm{C} 3 \mathrm{H} / \mathrm{HeJ}$ (female, 14-week-old, Jackson Laboratories, Miami, Fl., USA) mice. Lipopolysaccharide (LPS) from Escherichia coli O127:B8 (Difco), E. coli O111:B4 and Salmonella minnesota Re595 (List Biological Laboratories), and phytohaemagglutinin (PHA: Wellcome HAl6, Wellcome Reagents Ltd) were used as references.

Human monocyte migration. The stimulation of migration of human monocytes by SDS-SE ( $0 \cdot 1,1$ and $10 \mu \mathrm{g}$ $\mathrm{ml}^{-1}$ ) was assayed as described by Ogawa et al. (1982) using a multiwell chemotaxis assembly (Neuro Probe). Human peripheral blood monocytes were washed and resuspended to a cell density of $5 \times 10^{6}$ cells ml $^{-1}$ in Gey's BSA solution (Gey's balanced salt solution containing $2 \%, \mathrm{w} / \mathrm{v}$, bovine serum albumin and $20 \mathrm{mM}-\mathrm{HEPES}$ ). $N$ Formyl-L-methionyl-leucyl-phenylalanine (FMLP) and LPS-stimulated serum were used as positive controls. The migration index was expressed as the ratio of cells which migrated in the presence of test or positive control materials to cells which migrated in medium alone.

Cytotoxic action of SDS-SE preparations on fibroblasts derived from human gingiva. Cultures of human gingival fibroblasts were obtained from the resected gingiva of a patient with marginal periodontal disease. Isolated gingiva was treated with crystalline trypsin, and dispersed cells were propagated and maintained in Eagle MEM medium (Nissui Seiyaku Co.) supplemented with $10 \%(w / v)$ foetal bovine serum (FBS; Gibco). In the assay system, cells were used after subculturing several times.

The inhibition of cell proliferation caused by SDS-SE samples was measured by the reduction in $\left[{ }^{3} \mathrm{H}\right]$ thymidine incorporation, as follows. A confluent layer of human gingival fibroblasts grown in Eagle MEM medium supplemented with $5 \%$ FBS (Gibco) was trypsinized and dispersed in the medium. The cells collected by centrifugation were washed with Eagle MEM medium and resuspended in the same medium supplemented with $5 \%$ FBS to give $5 \times 10^{5}$ cells $\mathrm{ml}^{-1}$. Portions of the cell suspension $\left(200 \mu \mathrm{l}, 1 \times 10^{5}\right.$ cells $)$ were distributed to each well of plastic microplates ( 96 flat-bottom wells, Corning), and incubated in an atmosphere of air $/ \mathrm{CO}_{2}(95: 5, \mathrm{v} / \mathrm{v}$ ) at $37{ }^{\circ} \mathrm{C}$ for $48 \mathrm{~h}$. The supernatant medium of the cell monolayer was replaced by MEM medium supplemented with $0.5 \%$ FBS and incubated for a further $20 \mathrm{~h}$. SDS-SE samples were then added to the wells to give final concentrations of $0.5,2,8,10,20,50,100$ and $200 \mu \mathrm{g} \mathrm{m}^{-1}$, and incubated for $20 \mathrm{~h}$. [ $\left.{ }^{3} \mathrm{H}\right] \mathrm{Thymidine}(0.6 \mu \mathrm{Ci}$, $22.2 \mathrm{kBq}$; Amersham Japan) was added to each of the wells, and the plate was incubated for $3.5 \mathrm{~h}$ and then washed with PBS. Trichloroacetic acid $(200 \mu \mathrm{l}$ of $5 \%, \mathrm{w} / \mathrm{v}$, solution) was added to each well, followed by incubation at room temperature for $30 \mathrm{~min}$ and washing with ethanol/diethyl ether $(3: 1, v / v)$. The washed cells were digested with $0.3 \mathrm{M}-\mathrm{NaOH}$ at $37^{\circ} \mathrm{C}$ for $20 \mathrm{~min}$ and neutralized with $6 \mathrm{M}-\mathrm{HCl}$, then removed from the wells and dispersed into a suspension. The suspensions were transferred into scintillation vials and a cocktail of xylene base was added. Radioactivity was determined in a liquid scintillation counter (type LSC-700, Aloka, Tokyo). The assay was done with triplicate cultures and the mean value was determined.

The morphological change of fibroblast cells $\left(5 \times 10^{5}\right.$ cells per Petri dish, $35 \times 10 \mathrm{~mm}$, Corning) caused by the addition of SDS-SE samples $(0.5-200 \mu \mathrm{g})$ was observed after $24-48 \mathrm{~h}$ incubation, by Nikon inverted-type microscopy (Diaphoto-TMD, Nihhon Kogaku Industrial Co.).

\section{RESULTS}

Isolation of SE and SDS-SE. The recovery rates of SE and SDS-SE from whole cells of $A$. actinomycetemcomitans and $B$. gingivalis were $75-80 \%$ (SE, 27-31\%: SDS-SE, 49-51\%) and 66$72 \%$ (SE, 29-31\%; SDS-SE, 38-39\%), respectively. Contamination of the test specimens with endotoxin was checked by the Limulus Toxicolor test. Tests with equivalent weights of $E$. coli O111:B4 LPS were within the range 0.007-0.02\%.

Chemical composition of SDS-SE. The major components of SDS-SE were protein (42-78\%) and lipid $(9 \cdot 9-26.7 \%$ as fatty acids), with small amounts $(<5 \%)$ of hexose, pentose, methylpentose, hexosamine, phosphorus and glycerol (the two $B$. gingivalis strains, however, 
Table 1. Amino acid and amino sugar composition (residues per 100 amino acid residues) of SDS-SE preparations

\begin{tabular}{|c|c|c|c|c|c|c|}
\hline \multirow[b]{3}{*}{ Constituent } & \multicolumn{3}{|c|}{ A. actinomycetemcomitans } & \multirow{2}{*}{\multicolumn{2}{|c|}{ B. gingivalis }} & \multirow{3}{*}{$\begin{array}{c}\text { F. nucleatum } \\
\text { ATCC } \\
25586\end{array}$} \\
\hline & ATCC & ATCC & & & & \\
\hline & 29522 & 29524 & Y4 & 381 & 1021 & \\
\hline Aspartic acid & $10 \cdot 2$ & $10 \cdot 2$ & $9 \cdot 2$ & $7 \cdot 2$ & $7 \cdot 8$ & $10 \cdot 2$ \\
\hline Threonine & $5 \cdot 0$ & $5 \cdot 3$ & $4 \cdot 5$ & $3 \cdot 7$ & 3.9 & $5 \cdot 3$ \\
\hline Serine & $5 \cdot 0$ & 4.9 & $4 \cdot 7$ & $5 \cdot 4$ & $5 \cdot 8$ & $4 \cdot 8$ \\
\hline Glutamic acid & $11 \cdot 2$ & $11 \cdot 3$ & $10 \cdot 3$ & $6 \cdot 6$ & $8 \cdot 3$ & $11 \cdot 1$ \\
\hline Proline & $3 \cdot 5$ & $3 \cdot 6$ & $3 \cdot 6$ & $2 \cdot 9$ & $3 \cdot 0$ & $3 \cdot 3$ \\
\hline Glycine & $8 \cdot 1$ & 7.9 & $7 \cdot 8$ & $7 \cdot 2$ & $7 \cdot 6$ & $7 \cdot 6$ \\
\hline Alanine & $10 \cdot 2$ & $10 \cdot 0$ & $9 \cdot 4$ & 6.9 & $7 \cdot 4$ & $7 \cdot 4$ \\
\hline Cystine & ND & 0.4 & $0 \cdot 2$ & ND & ND & $0 \cdot 3$ \\
\hline Valine & 6.8 & $6 \cdot 6$ & $5 \cdot 8$ & 3.7 & $4 \cdot 2$ & $5 \cdot 3$ \\
\hline Diaminopimelic acid & 0.5 & 0.4 & $0 \cdot 2$ & 0.9 & $0 \cdot 2$ & ND \\
\hline Methionine & $0 \cdot 5$ & 0.2 & 0.2 & 0.6 & 0.7 & 1.8 \\
\hline Isoleucine & $4 \cdot 2$ & $4 \cdot 2$ & $2 \cdot 0$ & $2 \cdot 9$ & $3 \cdot 2$ & $5 \cdot 3$ \\
\hline Leucine & $7 \cdot 4$ & $7 \cdot 4$ & $7 \cdot 2$ & $5 \cdot 4$ & 6.0 & $7 \cdot 2$ \\
\hline Tyrosine & $2 \cdot 7$ & $2 \cdot 8$ & $2 \cdot 7$ & $2 \cdot 6$ & $2 \cdot 8$ & $3 \cdot 2$ \\
\hline Phenylalanine & $3 \cdot 2$ & $3 \cdot 2$ & $3 \cdot 1$ & $3 \cdot 2$ & $2 \cdot 8$ & $3 \cdot 4$ \\
\hline Ornithine & ND & ND & ND & ND & ND & $0 \cdot 1$ \\
\hline Lysine & $9 \cdot 7$ & $9 \cdot 4$ & 5.8 & 3.4 & $4 \cdot 4$ & $8 \cdot 7$ \\
\hline Ammonia & 3.8 & $3 \cdot 4$ & $13 \cdot 0$ & $11 \cdot 7$ & $11 \cdot 8$ & $8 \cdot 5$ \\
\hline Histidine & 1.6 & 1.7 & 1.8 & $1 \cdot 1$ & 1.4 & $1 \cdot 3$ \\
\hline Arginine & $4 \cdot 7$ & $4 \cdot 7$ & $4 \cdot 5$ & $2 \cdot 0$ & 3.5 & $3 \cdot 6$ \\
\hline Glucosamine & 0.9 & 1.5 & 2.9 & $18 \cdot 3$ & $14 \cdot 4$ & $1 \cdot 2$ \\
\hline Galactosamine & 0.9 & 0.9 & 0.9 & 0.9 & 0.7 & 0.1 \\
\hline
\end{tabular}

had a hexose content of 7.9-8.6\%). KDO contents were between 0.06 and $0.11 \%$. The amino acid and amino sugar composition of SDS-SE is shown in Table 1. The major amino acids detected in SDS-SE of $A$. actinomycetemcomitans and $F$. nucleatum were glutamic acid, aspartic acid, alanine and lysine. In the SDS-SE of $B$. gingivalis large amounts of glucosamine were detected. Diaminopimelic acid $(<0.9 \%$ ) was found but muramic acid and lanthionine were not detected in any of the specimens tested.

SDS-PAGE analysis of SDS-SE preparations. The SDS-PAGE pattern showed similarities among the three strains of $A$. actinomycetemcomitans and between the two strains of $B$. gingivalis (Fig. 1). The molecular masses of the main bands were 46, 38, 34 and $28 \mathrm{kDa}$ in the SDS-SE of $A$. actinomycetemcomitans, and 46 and $43 \mathrm{kDa}$ in that of $F$. nucleatum; the SDS-SE of $B$. gingivalis showed diffused bands of lower molecular mass.

Measurement of bound SDS. The amount of SDS in the test specimens of A. actinomycetemcomitans, $B$. gingivalis and $F$. nucleatum, determined by the partition detergent/dye salt method, was $10.9-11.5 \%, 12.4-14.8 \%$ and $8.9 \%$, respectively.

Fatty acid analysis. The fatty acid composition of SDS-SE preparations analysed by GLC is shown in Table 2. Large amounts of $\mathrm{C}_{14: 0}, \mathrm{C}_{16: 0}, \mathrm{C}_{16: 1}$ and 3-OH $\mathrm{C}_{8: 0}$ fatty acids and small amounts of 3-OH $\mathrm{C}_{14: 0}$ and $3-\mathrm{OH} \mathrm{C}_{\mathrm{i}-10: 0}$ fatty acids were found in the specimens of $A$. actinomycetemcomitans. In the specimens of $B$. gingivalis, 3- $-\mathrm{OH} \mathrm{C}_{8: 0}$ and 3-OH $\mathrm{C}_{\mathrm{i}-10: 0}$ fatty acids were found, but $\mathrm{C}_{16: 0}, \mathrm{C}_{16: 1}$ and $3-\mathrm{OH} \mathrm{C}_{14: 0}$ fatty acids were less abundant than in $A$. actinomycetemcomitans, and 3-OH $\mathrm{C}_{10: 0}, \mathrm{C}_{\mathrm{i}-13: 0}, \mathrm{C}_{\mathrm{i}-1 \text { 5:0 }}, 3-\mathrm{OH} \mathrm{C}_{\mathrm{i}-15: 0}$ and 3-OH $\mathrm{C}_{\mathrm{i}-17: 0}$ fatty acids, not found in $A$. actinomycetemcomitans, were detected.

Immunobiological activity in vivo and in vitro of SDS-SE preparations. The immunopotentiating activity on the cell-mediated and humoral immune responses of SDS-SE preparations was 


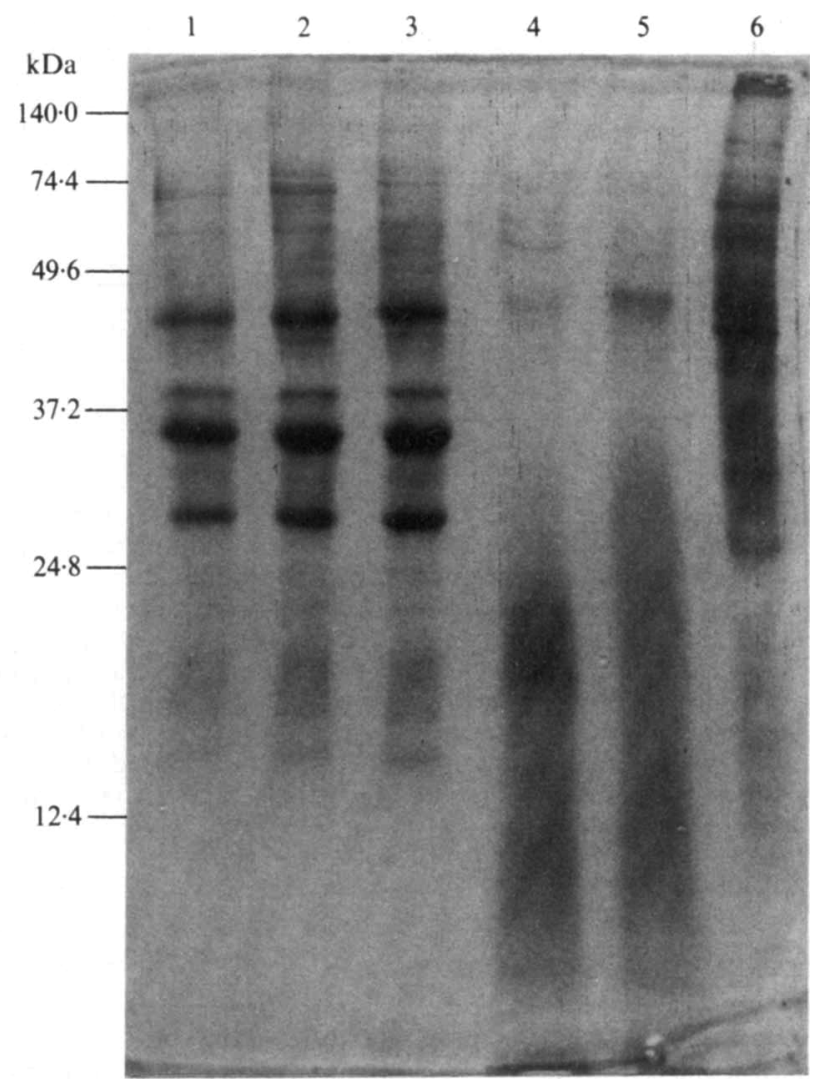

Fig. 1. SDS-PAGE of SDS-SE. Lanes: 1, A. actinomycetemcomitans ATCC 29522; 2, A. actinomycetemcomitans ATCC $29524 ; 3, A$. actinomycetemcomitans $Y 4 ; 4, B$. gingivalis $381 ; 5, B$. gingivalis $1021 ; 6, F$. nucleatum ATCC 25586.

Table 2. Fatty acid composition (\% of total fatty acids) of SDS-SE preparations

\begin{tabular}{|c|c|c|c|c|c|c|}
\hline \multirow[b]{3}{*}{ Fatty acid* } & \multicolumn{3}{|c|}{ A. actinomycetemcomitans } & & & \multirow{3}{*}{$\begin{array}{c}F . \text { nucleatum } \\
\text { ATCC } \\
25586\end{array}$} \\
\hline & \multirow{2}{*}{$\begin{array}{l}\text { ATCC } \\
29522\end{array}$} & \multirow{2}{*}{$\begin{array}{c}\text { ATCC } \\
29524\end{array}$} & \multirow[b]{2}{*}{ Y4 } & \multicolumn{2}{|c|}{ B. gingivalis } & \\
\hline & & & & 381 & 1021 & \\
\hline $12: 0$ & $\operatorname{tr}$ & $0 \cdot 1$ & tr. & ND & tr. & ND \\
\hline $14: 0$ & $11 \cdot 1$ & $12 \cdot 1$ & $12 \cdot 4$ & 1.8 & $4 \cdot 3$ & $4 \cdot 1$ \\
\hline $15: 0$ & $0 \cdot 1$ & $\operatorname{tr}$ & $\operatorname{tr}$ & ND & ND & ND \\
\hline $16: 0$ & $34 \cdot 1$ & 28.9 & $29 \cdot 4$ & $8 \cdot 4$ & 6.0 & $7 \cdot 4$ \\
\hline $16: 1$ & $25 \cdot 9$ & $15 \cdot 7$ & $23 \cdot 9$ & $2 \cdot 2$ & $2 \cdot 7$ & $8 \cdot 1$ \\
\hline $17: 0$ & ND & ND & ND & ND & tr. & ND \\
\hline $18: 0$ & 1.6 & 1.6 & $1 \cdot 7$ & 0.5 & ND & $1 \cdot 5$ \\
\hline $18: 1$ & 1.4 & 0.9 & $1 \cdot 2$ & $0 \cdot 4$ & 0.7 & $18 \cdot 8$ \\
\hline $3-\mathrm{OH} \quad 8: 0$ & $12 \cdot 7$ & 28.9 & $20 \cdot 8$ & $15 \cdot 3$ & $11 \cdot 7$ & $29 \cdot 0$ \\
\hline $3-\mathrm{OH} 14: 0$ & $4 \cdot 7$ & $4 \cdot 1$ & $5 \cdot 4$ & $0 \cdot 2$ & $0 \cdot 2$ & 1.6 \\
\hline $3-\mathrm{OH} 16: 0$ & ND & ND & ND & $3 \cdot \overline{5}$ & $4 \cdot 4$ & ND \\
\hline$i-13$ & ND & ND & ND & $1 \cdot 5$ & $2 \cdot 2$ & ND \\
\hline$i-15$ & ND & ND & ND & $39 \cdot 4$ & $38 \cdot 4$ & ND \\
\hline $3-\mathrm{OH} i-10: 0$ & 3.8 & $4 \cdot 6$ & 3.9 & 6.5 & 6.0 & $7 \cdot 4$ \\
\hline $3-\mathrm{OH} i-15: 0$ & ND & ND & ND & 3.5 & $2 \cdot 2$ & ND \\
\hline $3-\mathrm{OH} i-17: 0$ & ND & ND & ND & $15 \cdot 5$ & $10 \cdot 0$ & ND \\
\hline Unknown & $4 \cdot 6$ & $3 \cdot 1$ & $1 \cdot 3$ & $1 \cdot 3$ & 1.5 & $5 \cdot 1$ \\
\hline
\end{tabular}

tr., trace: ND, not detected.

* $i$, iso-acid : 3-OH, 3-hydroxy acid; $16: 0$, a straight-chain saturated acid of 16 carbons; $16: 1$, a straight-chain unsaturated acid of 16 carbons with one double bond. 


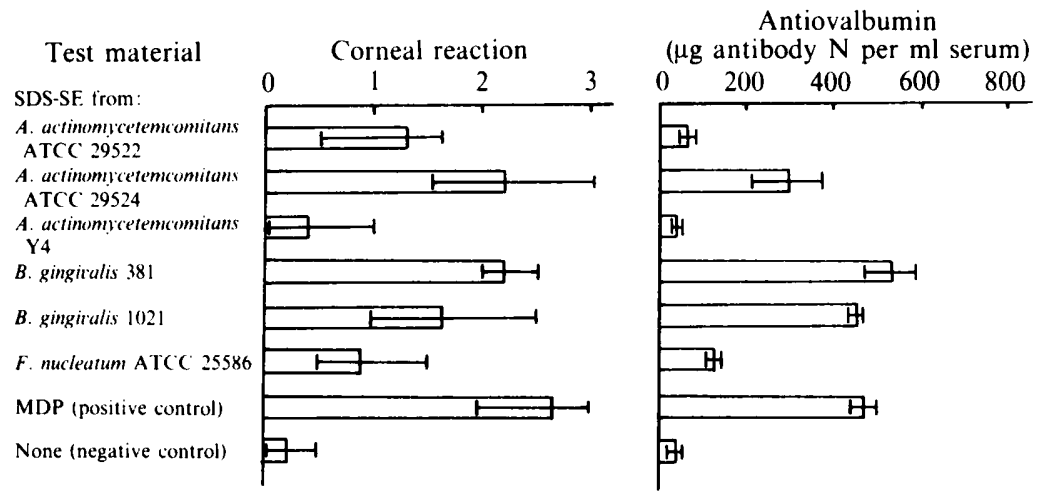

Fig. 2. Immunopotentiating activity of SDS-SE on cellular and humoral immunity to ovalbumin. Groups of five female albino guinea-pigs were immunized by footpad injection of $1 \mathrm{mg}$ ovalbumin with $0.1 \mathrm{mg}$ SDS-SE or MDP (muramyl dipeptide) as an emulsion in PBS/Freund's incomplete adjuvant with ovalbumin as a test antigen. The corneal reaction was measured $21 \mathrm{~d}$ after sensitization to evaluate delayed-type hypersensitivity, and the mean and range of the response are shown. The guinea pigs were given an intracorneal injection of $2 \%(\mathrm{w} / \mathrm{v})$ ovalbumin in saline to make a transient white spot of opacity about $5 \mathrm{~mm}$ in diameter. The eyes were examined after 24 and $48 \mathrm{~h}$ and the corneal reaction was graded from 3 (whole cornea thickened, opaque and greyish-white) to 1 (slight opacity). When no visible difference from the uninjected eye was detected the reaction was graded as 0 . The antiovalbumin precipitin level ( $\mu \mathrm{g}$ antibody nitrogen per $\mathrm{ml}$ serum) was measured $30 \mathrm{~d}$ after sensitization, and the mean and standard error are shown.

determined (Fig. 2). SDS-SE of A. actinomycetemcomitans ATCC 29524 and B. gingivalis 381 and 1021 potentiated both induction of a delayed-type hypersensitivity and antibody formation against the antigen, ovalbumin. The activity was as potent as that of muramyl dipeptide (MDP). The mitogenic activity of SDS-SE preparations on splenocytes of athymic BALB/c nu/nu mice was tested using doses of $0.1,1.0$ and $10 \mu \mathrm{g}$ (Fig. $3 a$ ). All the preparations showed mitogenic activity more potent than that of $E$. coli LPS. The mitogenic activity of the specimens on splenocytes of $\mathrm{C} 3 \mathrm{H} / \mathrm{HeN}$ (LPS high responder) and $\mathrm{C} 3 \mathrm{H} / \mathrm{HeJ}$ (LPS low responder) mice was also examined (Fig. $3 b$ ). Mitogenic activity of SDS-SE preparations was observed in both types of mice; this activity was more potent than that found with $E$. coli LPS or $S$. minnesota LPS. The human peripheral monocyte migration-stimulating activity of SDS-SE specimens was lower than that found with FMLP $\left(10^{-8} \mathbf{M}\right)$ or with LPS-stimulated serum $(1: 10)$, but the SDS-SE of $F$. nucleatum and $A$. actinomycetemcomitans ATCC 29522 and Y4 (dose of $1.0 \mu \mathrm{g} \mathrm{ml}^{-1}$ ) showed a stimulation index of more than 3.0. The specimens of $B$. gingivalis $1021\left(1.0 \mu \mathrm{g} \mathrm{ml}^{-1}\right), B$. gingivalis $381\left(10.0 \mu \mathrm{g} \mathrm{ml}^{-1}\right)$, A. actinomycetemcomitans ATCC $29524\left(0.1 \mu \mathrm{g} \mathrm{ml}^{-1}\right)$ showed stimulation indices of $2-3$ (Fig. 4).

The effect of SDS-SE preparations on DNA synthesis in human fibroblasts was examined. Incorporation of $\left[{ }^{3} \mathrm{H}\right]$ thymidine by human gingival fibroblasts was inhibited completely by all the SDS-SE preparations at $20 \cdot 0 \mu \mathrm{g} \mathrm{ml}^{-1}$ (Fig. 5). However, the dose required to cause $50 \%$ inhibiton of incorporation was lowest for $A$. actinomycetemcomitans SDS-SE. The effect of SDS alone $\left(0 \cdot 5,1 \cdot 0,2 \cdot 0\right.$ and $5.0 \mu \mathrm{g} \mathrm{ml}^{-1}$, i.e. equivalent amounts of SDS estimated to be present in each of the preparations) on fibroblasts was also tested (Fig. 5): it had no inhibitory effect.

The effect of SDS-SE preparations on the morphology of fibroblasts was tested. Morphological changes, which involved rounding of the cells and a decrease in the number of cells attached to the glass surface, were graded from A to D, with A representing the control culture of fibroblasts, B representing partially damaged cells and a small number of round cells, $C$ representing many damaged cells and many round cells, and $D$ representing a high proportion of damaged cells. Fig. 6 shows representative examples of morphological changes caused by the addition of SDS-SE of $B$. gingivalis 381 (grade B, $100 \mu \mathrm{g} \mathrm{ml}^{-1}, 24 \mathrm{~h} ; \mathrm{C}, 100 \mu \mathrm{g} \mathrm{ml}^{-1}, 48 \mathrm{~h}$; D, $200 \mu \mathrm{g} \mathrm{ml}^{-1}, 48 \mathrm{~h}$ ). The scores for morphological changes caused by the addition of SDS-SE 

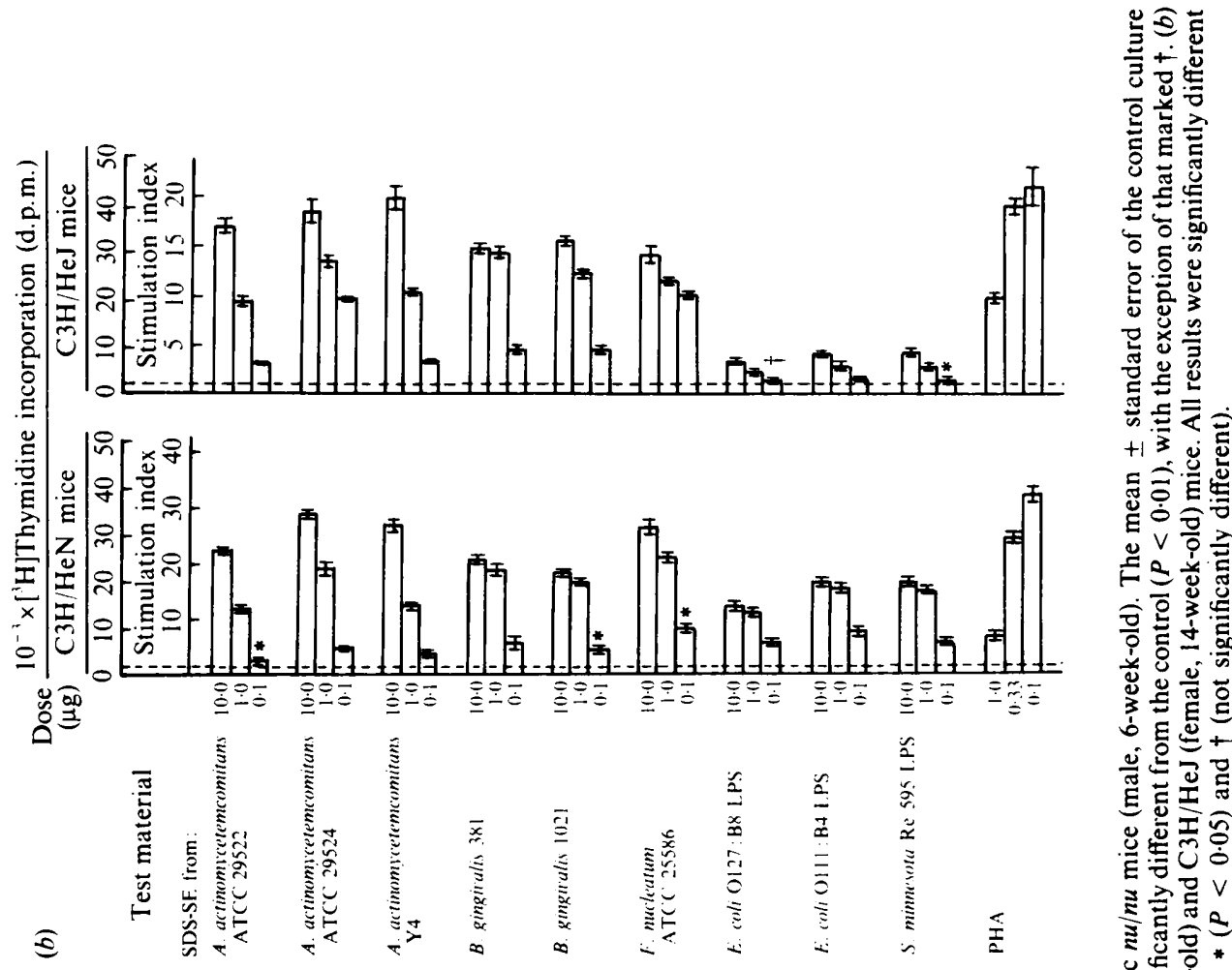

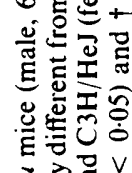

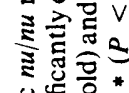

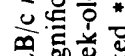
的总

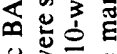

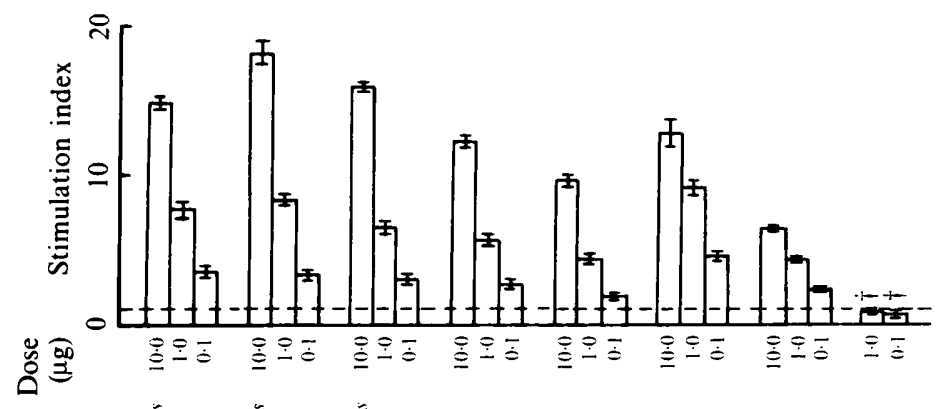

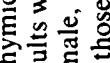

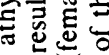

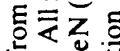
舟

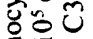

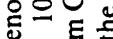
公乐

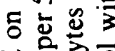

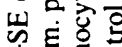

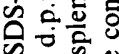

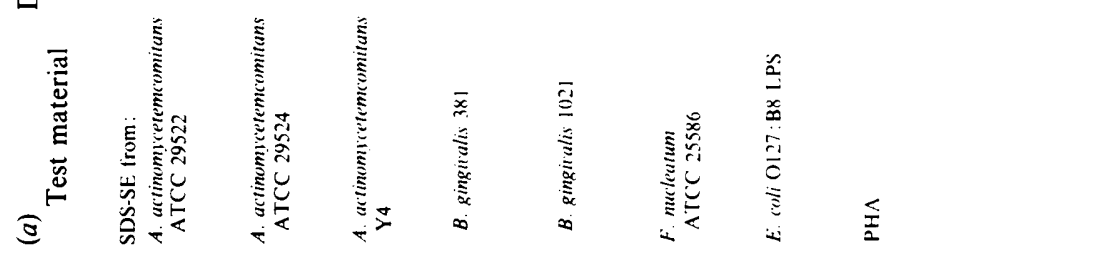
흥 证崖 路 的 额论 ब品. m. 弦

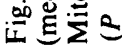




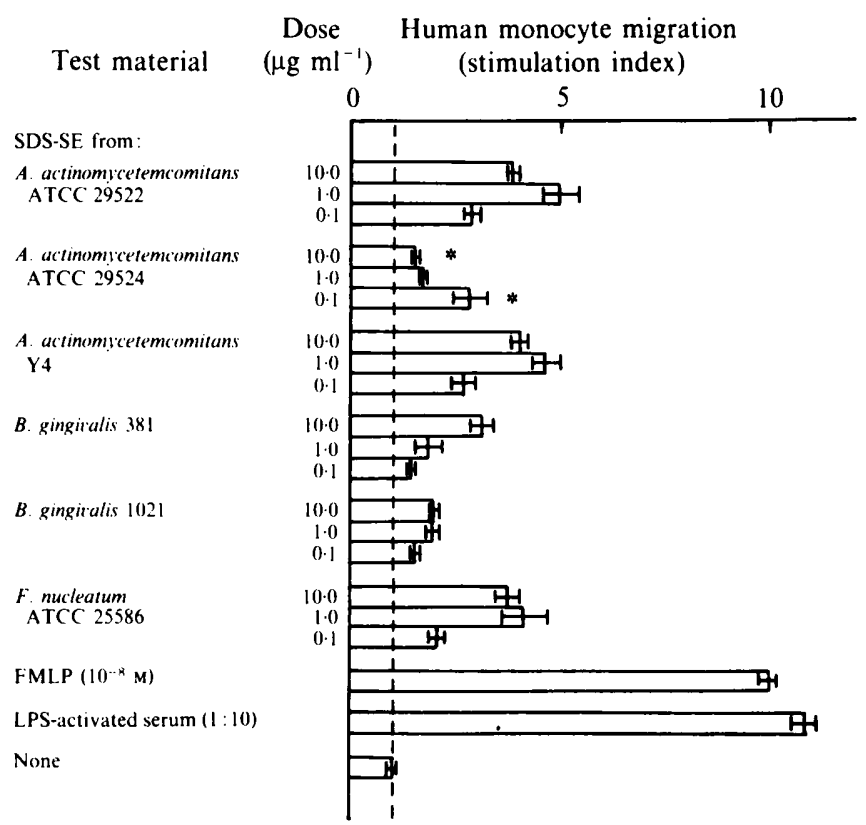

Fig. 4. Migration-stimulating activity of SDS-SE on human peripheral blood monocytes. The mean number \pm standard error of migrated monocytes of the positive controls was $73 \cdot 3 \pm 2 \cdot 2$ for FMLP $\left(10^{-8} \mathrm{M}\right)$ and $79 \cdot 3 \pm 3.3$ for LPS-activated serum $(1: 10)$, and that of the negative control was $7 \cdot 3 \pm 0.3$. All results were significantly different from the control $(P<0.01)$ with the exception of that marked * $(P<0.05)$.

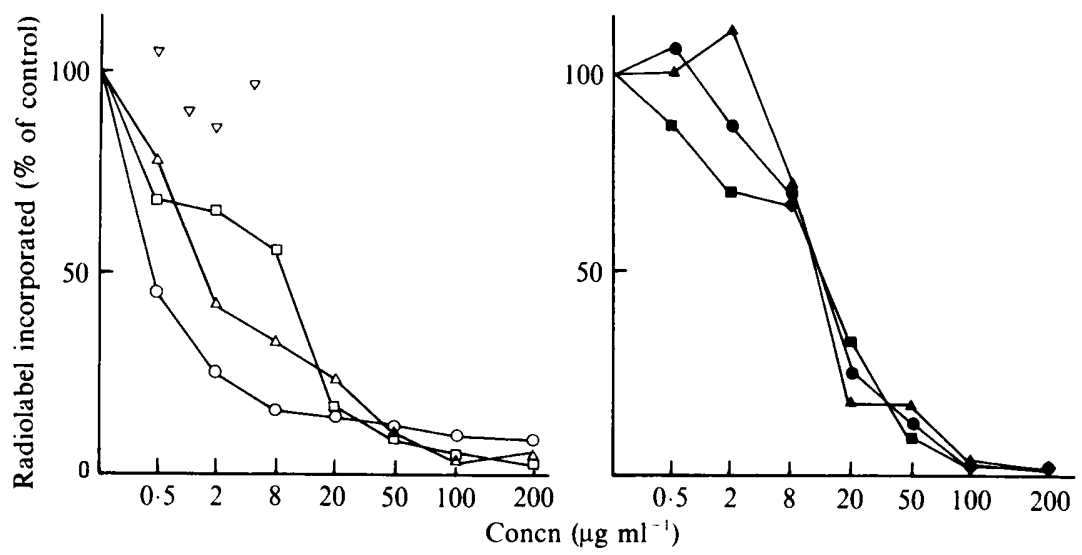

Fig. 5. Effects of SDS-SE and SDS on the synthesis of DNA by human gingival fibroblasts. $\triangle, A$. actinomycetemcomitans ATCC 29522; $\square$, A. actinomycetemcomitans A TCC 29524; O, A. actinomycetemcomitans Y4; $\nabla$, SDS; , B. gingivalis $381 ; \Delta, B$. gingivalis $1021 ; \square, F$. nucleatum ATCC 25586.

specimens $\left(100 \mu \mathrm{g} \mathrm{ml}^{-1}\right)$ after 24 or $48 \mathrm{~h}$ were: B. gingivalis 1021 (D, $\left.24 \mathrm{~h}\right), F$. nucleatum (D, $48 \mathrm{~h})$, B. gingivalis 381 (C, $48 \mathrm{~h})$, A. actinomycetemcomitans ATCC 29522 (B, $48 \mathrm{~h})$, ATCC 29524 (B, $48 \mathrm{~h}$ ). However, SDS-SE of $A$. actinomycetemcomitans Y4 caused definite morphological change of fibroblasts (grade $\mathrm{C}$ ) after $48 \mathrm{~h}$ incubation only at a concentration of $200 \mu \mathrm{g} \mathrm{ml}^{-1}$. 

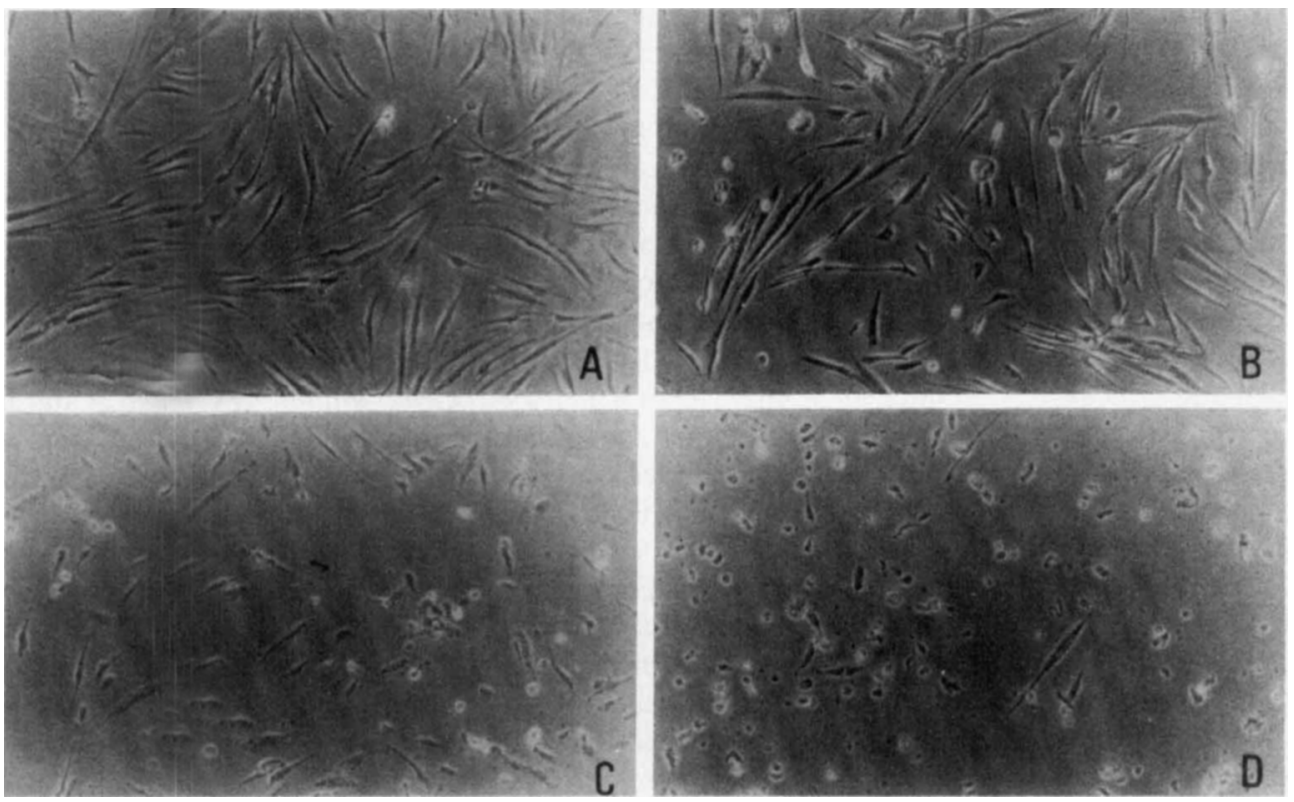

Fig. 6. Effect of $B$. gingivalis 381 SDS-SE on human gingival fibroblasts. Degree of morphological change: A, control cells $(48 \mathrm{~h}) ; \mathrm{B}$, partially damaged cells $(100 \mu \mathrm{g}, 24 \mathrm{~h}) ; \mathrm{C}$, severely damaged cells $(100 \mu \mathrm{g}, 48 \mathrm{~h}) ; \mathrm{D}$, completely damaged cells $(200 \mu \mathrm{g}, 48 \mathrm{~h})$. Magnification $\times 200$.

\section{DISCUSSION}

A. actinomycetemcomitans is a predominant bacterium isolated from patients with localized juvenile periodontitis, and a high antibody titre is also found in these patients (Slots \& Genco, 1984). B. gingivalis has been isolated from the lesion site of rapidly progressing alveolar bone destruction and advancing periodontal lesion with severe gingivitis. Higher levels of immunoglobulin $G$ were observed in patients with severe adult periodontitis and generalized juvenile periodontitis than in healthy controls (Slots \& Genco, 1984). F. nucleatum is frequently isolated from human gingival crevice regions and is the predominant isolate from patients with chronic gingivitis, early and advanced periodontitis and juvenile periodontitis (Slots \& Genco, 1984).

Several authors have reported the biological activity (direct toxicity) of SE from periodontopathic bacteria: leucotoxic activity of extracts of $A$. actinomycetemcomitans, and inhibitory activity of extracts of $A$. actinomycetemcomitans, Capnocytophaga suptigena and Bacteroides asaccharolyticus on the proliferation of human mucosal epithelial cells and fibroblasts (Stevens et al., 1980, 1983; Kamen, 1983) have been described. Similar biological activities of cell envelope components of Gram-negative bacteria, especially LPS, lipid A and peptidoglycan have been reported (Sveen, 1977; Kiley \& Holt, 1980; Iino \& Hopps, 1984). Treatment of cell envelopes with SDS solubilizes both the inner and outer membranes (Filip et al., 1973); the major constituents of the SDS-SE preparations reported here were protein and lipid. In the fatty acid analysis of SDS-SE of $A$. actinomycetemcomitans, 3-OH $\mathrm{C}_{8: 0}$ and 3-OH $\mathrm{C}_{\mathrm{i}-10: 0}$ fatty acids were found in addition to $\mathrm{C}_{16: 0}, \mathrm{C}_{16: 1}$ and 3-OH $\mathrm{C}_{\mathrm{i}-14: 0}$ fatty acids. The former two fatty acids were not found in the cell membrane of $A$. actinomycetemcomitans by Calhoon $e t$ al. (1981). In B. gingivalis SDS-SE, the concentration of $\mathrm{C}_{\mathrm{i}-15: 0}$ detected agreed with the report of Mayberry (1980), and 3-OH C $16: 0,3-\mathrm{OH} \mathrm{C} \mathrm{C}_{\mathrm{i}-15: 0}$ and 3-OH C $\mathrm{C}_{\mathrm{i}-17: 0}$ fatty acids, not found in $A$. actinomycetemcomitans SDS-SE, were detected in addition to 3-OH $\mathrm{C}_{8: 0}$. Complete identification of the fatty acids will require analysis by GC-MS.

The KDO content of the SDS-SE preparations was $<0.01 \%$, and the endotoxin content was 
$0.007-0.02 \%$, suggesting that endotoxin contamination was negligible. The splenocytes of $\mathrm{C} 3 \mathrm{H} / \mathrm{HeJ}$ (LPS non-responder) mice responded to the SDS-SE as well as those of $\mathrm{C} 3 \mathrm{H} / \mathrm{HeN}$ mice, indicating that a B cell mitogen other than LPS was involved in SDS-SE (however, it should be stated that $B$. gingivalis LPS extracted by the phenol/water method, which had no detectable heptose and $\mathrm{KDO}$, elicited a response with splenocytes of $\mathrm{C} 3 \mathrm{H} / \mathrm{HeJ}$ mice: Koga et al., 1985). Neither muramic acid nor lanthionine was detected in the SDS-SE preparations, and diaminopimelic acid was present in trace amounts, suggesting minimal contamination with peptidoglycan. The results suggest that the major components solubilized by SDS from the cell envelopes of periodontopathic bacteria are essentially derived from the inner membrane.

Adjuvant activity of SDS-SE was tested using guinea-pigs with incomplete Freund's adjuvant and ovalbumin as the immunogen. SDS-SE from $A$. actinomycetemcomitans ATCC 29524 and $B$. gingivalis 381 and 1021 potentiated both cellular and humoral immunity, but the SDS-SE from $A$. actinomycetemcomitans ATCC 29522 potentiated only cellular immunity. The reason for this difference among the preparations of SDS-SE is unknown. Mitogenic activity on splenocytes from mice, exceeding that of authentic LPS, was detected in all the SDS-SE preparations. Migration-stimulating activity toward human peripheral monocytes was also detected but the SDS-SE preparations of $A$. actinomycetemcomitans ATCC 29524 and B. gingivalis 381 and 1021, which were adjuvant-active, were less active in this assay.

The precise component, whether protein and/or lipid, of SDS-SE responsible for the immunobiological activity is unknown. We tried to remove lipid from SDS-SE by chloroform extraction, but lipid removal was incomplete and partial inhibitory activity on the proliferation of gingival fibroblasts remained.

Nagai et al. (1984) used SE and SDS-SE from periodontopathic bacteria (A. actinomycetemcomitans and $B$. gingivalis) as test antigens for an ELISA to detect serum antibody in patients with various types of periodontal disease. They found that both antigens were reactive to the test sera, but some of the sera (31-59\%) showed different antibody titres against each test antigen.

Soluble extracts obtained by SDS treatment from cell-surface components of periodontopathic bacteria may contain an active principle responsible for direct toxicity in collagenoustissue destruction by affecting gingival fibroblasts, and immunopotentiating activity and activation of macrophage-lymphocyte interactions may contribute to sensitization of patients to the periodontopathic antigens via humoral and/or cell-mediated immune mechanisms.

We are indebted to D. E. S. Stewart-Tull, University of Glasgow, Glasgow, UK, for critical reading of the manuscript.

\section{REFERENCES}

Ashwell, G. (1957). Colorimetric analysis of sugars. Methods in Enzymology 3, 84-90.

Baehni, P., Tsai, C.-C., Mcarthur, W. P., HamMOND, B. F. \& TAIChMAN, N. S. (1979). Interaction of inflammatory cells and oral microorganisms. VIII. Detection of leukotoxic activity of a plaquederived gram-negative microorganism. Infection and Immunity 24, 233-243.

Baehni, P. C., Tsai, C.C., Mcarthur, W. P., Hammond, B. F., Shenker, B. J. \& Taichman, N. S. (1981). Leukotoxic activity in different strains of the bacterium Actinobacillus actinomycetemcomitans isolated from juvenile periodontitis in man. Archives of Oral Biology 26, 671-676.

Calhoon, D. A., Mayberry, W. R. \& Slots, J. (1981). Cellular fatty acid and soluble protein composition of Actinobacillus actinomycetemcomitans and related organisms. Journal of Clinical Microbiology 14, 376382.

Dische, Z. \& Shettles, L. B. (1948). A specific color reaction of methylpentoses and a spectrophoto- metric micromethod for their determination. Journal of Biological Chemistry 175, 595-603.

Filip, C., Fletcher, G., WulfF, J. L. \& Earhart, C. F. (1973). Solubilization of the cytroplasmic membrane of Escherichia coli by the ionic detergent sodium lauryl sarcosinate. Journal of Bacteriology $115,717-722$.

HausmanN, E., Luderitz, O., Knox, K. \& Weinfeld, N. (1975). Structural requirements for bone resorption by endotoxin and lipoteichoic acid. Journal of Dental Research (Special Issue) B54, B94-B99.

HAYASHI, K. (1975). A rapid determination of sodium dodecyl sulfate with methylene blue. Analytical Biochemistry 67, 503-506.

IINO, Y. \& HoPPS, R. M. (1984). The bone-resorbing activities in tissue culture of lipopolysaccharides from the bacteria Actinobacillus actinomycetemcomitans, Bacteroides gingivalis and Capnocytophaga ochracea isolated from human mouths. Archives of Oral Biology 29, 59-63.

IKemoto, S., КатоH, K. \& Komagata, K. (1978). 
Cellular fatty acid composition in methanol-utilizing bacteria. Journal of General and Applied Microbiology 24, 41-49.

Iwanaga, S., Morita, T., Harada, T., Nakamura, S., Niwa, M., TAKada, K., Kimura, T. \& SaKakibara, S. (1978). Chromogenic substrates for horseshoe crab clotting enzyme. Its application for the assay of bacterial endotoxins. Haemostasis 7, 183-188.

KAMEN, P. R. (1983). Inhibition of keratinocyte proliferation by extracts of Actinobacillus actinomycetemcomitans. Infection and Immunity 42, 1191-1194.

KILEY, P. \& HolT, S. C. (1980). Characterization of the lipopolysaccharide from Actinobacillus actinomycetemcomitans Y4 and N27. Infection and Immunity 30, 862-873.

Koga, T., Nishihara, T., Fujiwara, T., Nishizawa, T., Okahashi, N., Noguchi, T. \& Hamada, S. (1985). Biochemical and immunobiological properties of lipopolysaccharide (LPS) from Bacteroides gingivalis and comparison with LPS from Escherichia coli. Infection and Immunity 47, 638-647.

Kotani, S., Narita, T., Stewart-Tull, D. E. S., Shimono, T., Watanabe, Y., Kato, K. \& Iwata, S. (1975). Immunoadjuvant activities of cell walls and their water-soluble fractions prepared from various gram-positive bacteria. Biken Journal 18, 77-92.

LAEMMLI, U. K. (1970). Cleavage of structural proteins during the assembly of the head of bacteriophage T4. Nature, London 227, 680-685.

LAMBeRT, M. \& NeISH, A. C. (1950). Rapid method for estimation of glycerol in fermentation solutions. Canadian Journal of Research 28, section B, 83-89.

LEHNER, T. (1975). Immunological aspects of dental caries and periodontal disease. British Medical Bulletin 31, 125-130.

LOWRY, O. H., ROBERTS, N. R., LEINER, K. Y., WU, M.-L. \& FARR, A. L. (1954). The quantitative histochemistry of brain. 1. Chemical methods. Journal of Biological Chemistry 207, 1-17.

Macrina, F. L. \& Ranney, R. R. (1982). Periodontal disease: microbiological and epidemiological aspects. In Dental Microbiology, pp. 732-752. Edited by J. P. McGhee, S. M. Michalek \& G. H. Cassell. Philadelphia: Harper \& Row.

MAYBERRY, W. R. (1980). Hydroxy fatty acids in Bacteroides species: D-(-)-3-hydroxy-15-methylhexadecanoate and its homologs. Journal of Bacteriology 143, 582-587.

Murayama, Y., Muranishi, K., OKada, H., Kato, K., Kotani, S., Takada, H., Tsujimoto, M., KaWASAKI, A. \& OgaWA, T. (1982). Immunological activities of Capnocytophaga cellular components. Infection and Immunity 36, 876-884.

Nagai, A., Kurihara, H., Kinoshita, M., Matsuo, M., Shimuzu, H., Toda, Y., Nomura, Y., MUR- ayama, Y., KoKeguchi, S. \& Kato, K. (1984). Examination of enzyme-linked immunosorbent assay for serum antibodies against periodontally associated microorganisms. Journal of the Japanese Association of Periodontology 26, 317-328 (in Japanese).

Ogawa, T., Kotani, S., Fukuda, K., Tsukamoto, Y., Mori, M., Kusumoto, S. \& Shiba, T. (1982). Stimulation of migration of human monocytes by bacterial cell walls and muramyl peptides. Infection and Immunity 38, 817-824.

OHTA, H. \& HATTORI, T. (1983). Agromonas oligotrophica gen. nov., sp. nov., a nitrogen-fixing oligotrophic bacterium. Antonie van Leeuwenhoek 49, 429-446.

Page, R. C. \& Schroeder, H. E. (1981). Current status of the host response in chronic marginal periodontitis. Journal of Periodontology 52, 477-491.

Progulske, A., Mishell, R., Trummel, C. \& Holt, S. C. (1984). Biological activities of Eikenella corrodens outer membrane and lipopolysaccharide. Infection and Immunity 43, 178-182.

Singer, R. E. \& BuCKneR, B. A. (1981). Butyrate and propionate: important components of toxic dental plaque extracts. Infection and Immunity 32, 458-463.

Slots, J. \& GenCo, R. J. (1984). Black-pigmented Bacteroides species, Capnocytophaga species, and Actinobacillus actinomycetemcomitans in human periodontal disease: virulence factors in colonization, survival, and tissue destruction. Journal of Dental Research 63, 412-421.

Stevens, R. H. Sella, M. N., Shapira, J. \& Hammond, B. F. (1980). Detection of a fibroblast proliferation inhibitory factor from Capnocytophaga sputigena. Infection and Immunity 27, 271-275.

Stevens, R. H., Gatewood, C. \& Hammond, B. F. (1983). Cytotoxicity of the bacterium Actinobacillus actinomycetemcomitans extracts in human gingival fibroblasts. Archives of Oral Biology 28, 981-987.

SVEEN, K. (1977). The capacity of lipopolysaccharides from bacteroides, fusobacterium, and veillonella to produce skin inflammation and the local generalized Schwartzman reaction in rabbits. Journal of Periodontal Research 12, 340-350.

Takada, H., Tsujimoto, M., Kotani, S., Kusumoto, S., Inage, M., Shiba, T., Nagao, S., Yano, I., Kawata, S. \& Yokogawa, K. (1979). Mitogenic effects of bacterial cell walls, their fragments, and related synthetic compounds on thymocytes and splenocytes of guinea pigs. Infection and Immunity $\mathbf{2 5}$, 645-652.

Weissbach, A. \& HuRwitz, J. (1959). The formation of 2-keto-3-deoxyheptonic acid in extracts of Escherichia coli B. Journal Biological Chemistry 234, 705709. 